\title{
Engineering development of the territory - as a factor of investment attractiveness of the region
}

\author{
Anna Ermakova ${ }^{1, *}$ \\ ${ }^{1}$ Industrial University of Tyumen, 625001, Tyumen city, Russia
}

\begin{abstract}
This article discusses several similar investment sites located in the municipal district. Through the development of transport infrastructure and engineering development of the territory, it is planned to attract the attention of potential investors. The author analyzes the necessary costs for the construction of engineering communications and transport infrastructure. The most attractive land plot for potential investors has been identified.
\end{abstract}

\section{Introduction}

The problem of lack of available land for urban development is very relevant. The shortage of land in municipalities is due to the already formed main buildings, a significant part of which is cultural heritage. Assessment of investment attractiveness of land plots plays a special role in the effective implementation of investment projects. The effectiveness of the project is evaluated through the parameters of profit and speed of implementation of the "construction product", taking into account the implementation of all legal requirements, the principle of physical feasibility and ensuring the comfort of life [1].

The concept of investment attractiveness is quite extensive. This category is used not only for evaluating land, capital construction projects, and enterprises, but also for cities, regions, countries, and even continents when implementing investment projects and evaluating their effectiveness [2].

The investment attractiveness of land plots for construction should be understood as a set of factors (criteria) of land plots that determine the possibility of obtaining high incomes for the created objects and form a potential demand.

The purpose of this study is to study the investment attractiveness of land plots due to the engineering arrangement of the territory.

The object of research is land plots located in the Tyumen municipal district [3].

The methodological basis of the research is the theoretical and practical developments of Russian and foreign scientists and economists, as well as legislative and regulatory acts of state authorities on regulating investment activities in the Russian Federation.

\footnotetext{
*Corresponding author: ermakovaam@tyuiu.ru
} 


\section{Materials and methods}

Tyumen region has great potential and is a very attractive municipal area for citizens to live and do business.

It is located in close proximity to the center of strategic decision-making in the politics and economy of the entire region [4].

The key advantage of the district is a high concentration of human (intellectual) capital, which is explained by:

- high population (first place in the rating of municipal districts by population);

- high concentration (density) of population (first place in the rating of municipal districts by population density);

- attractiveness of the district for migrants from neighboring countries and Central Asia (first place in the rating of municipal districts in terms of migration);

- diversity of national and cultural potential.

The territorial and spatial advantages of the district include $[5,6]$ :

- favorable transport and geographical location (four Federal highways are located on the territory of the district, connecting the district with the Northern, Western, Eastern, and southern sides;

- diversity of the land Fund by categories and types of permitted use (forest land, agricultural land, industrial land, land of specially protected territories and objects, land of settlements, reserve land);

- the presence of large natural areas, large and small rivers, lakes (the district has large rivers Tura and Pyshma, as well as 26 small rivers, there are 407 lakes);

- availability of mineral resources (discovered deposits of underground water, lake sapropel, sand, clay).

The economic advantages of the district are explained by [7,8,9]:

- high involvement in the economy of the region in the production of certain types of products (the Tyumen region accounts for $50 \%$ of the regional production of non-metallic construction materials; $50 \%$ of the production of natural sand; more than $90 \%$ of the production of meat and poultry offal; $50 \%$ of the production of semi-finished meat chilled, frozen and frozen, etc.);

- the presence of leading large manufacturing companies that provide a relatively high level of volume of shipped goods of their own production, performed works and services on their own, large organizations;

- relatively high business activity of small and medium-sized enterprises.

Thus, the investment attractiveness of the Tyumen region is favorable for the formation of investment land plots, therefore, there is an urgent need for engineering development of the territory (figure 1.).

Under the influence of investment attractiveness factors, similar land plots with similar characteristics were also formed on the territory of the Tyumen region: the type of permitfor the organization of industrial production and the category of land - on the lands of settlements (Fig. 2-4).

The investment sites are located in the largest Chervishevsky municipality of the Tyumen Region. The population of 7,368 people $[10,11,12,13]$. 


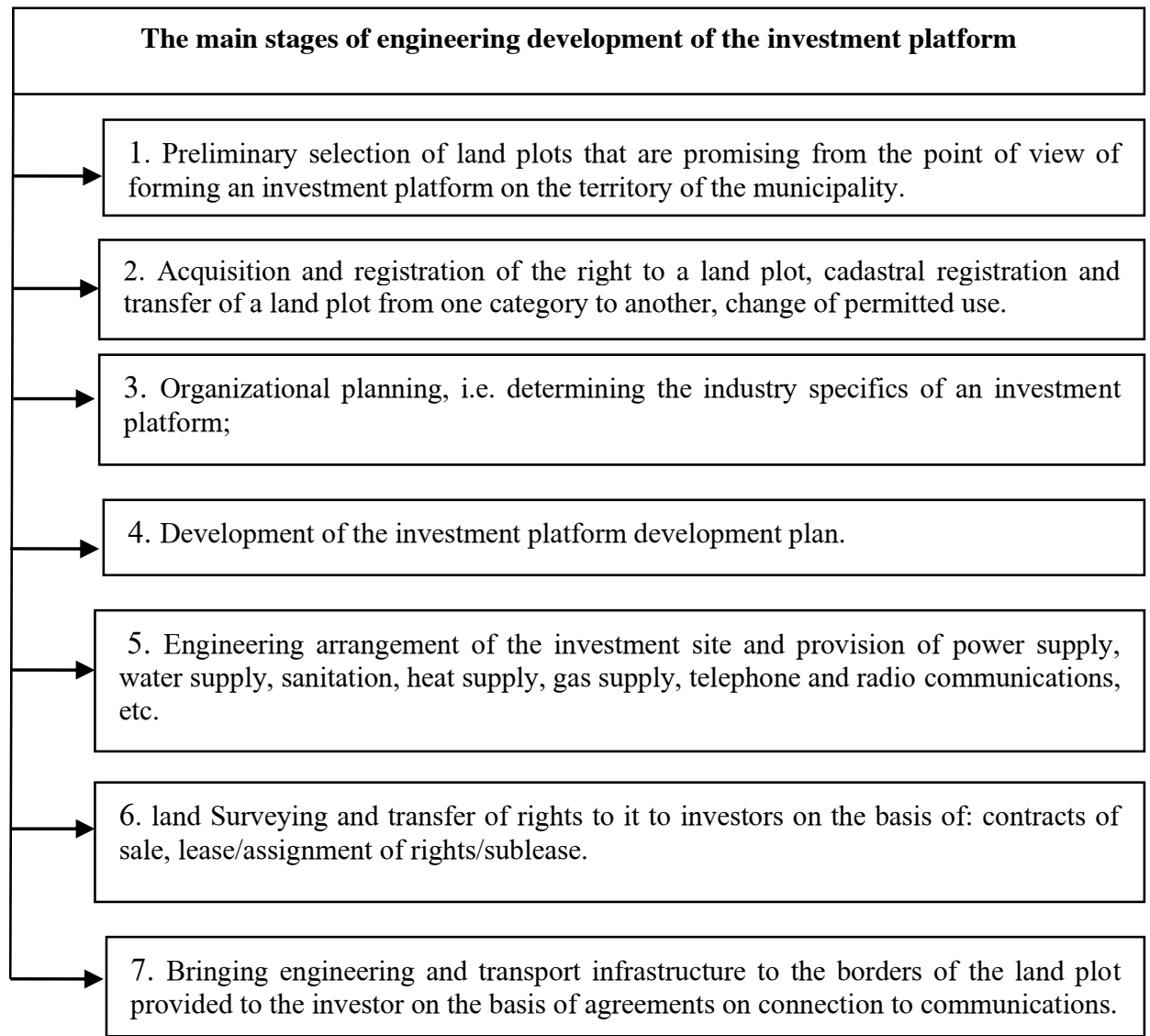

Fig. 1. The main stages of engineering development of the investment platform.

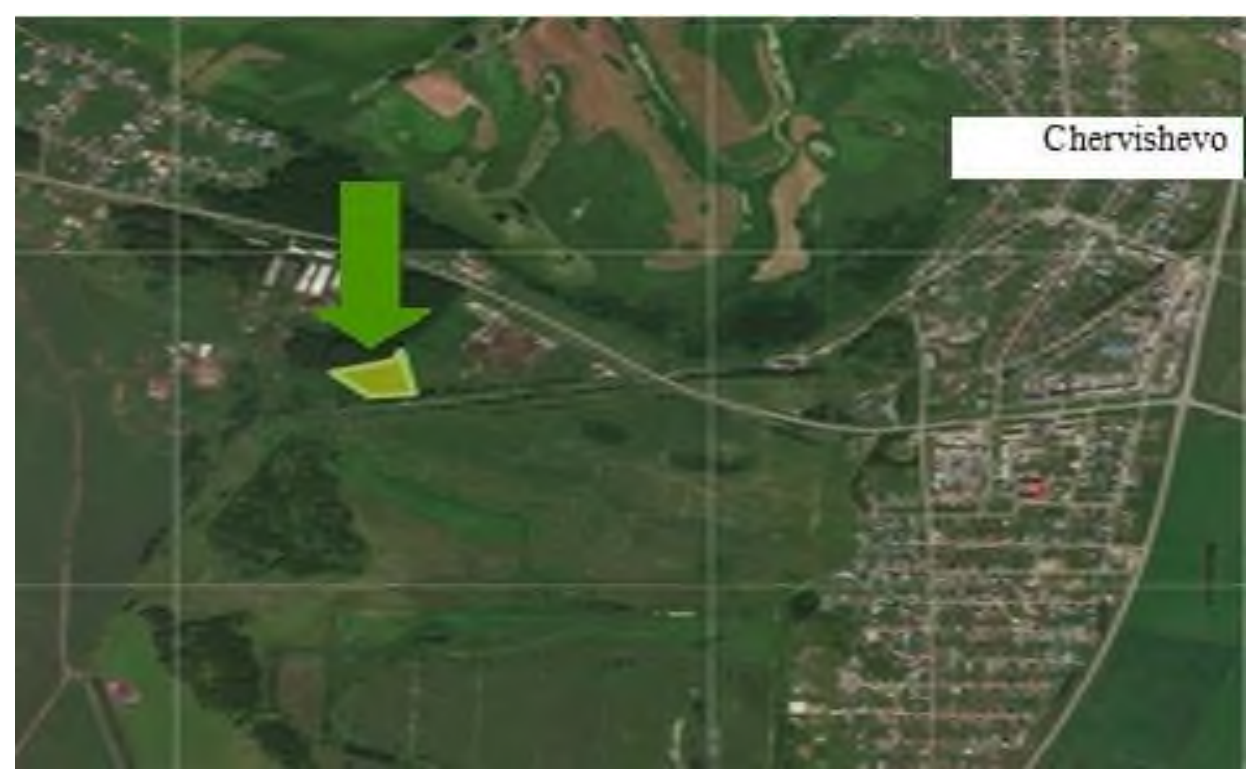

Fig. 2. Diagram of the location of investment site №1. 


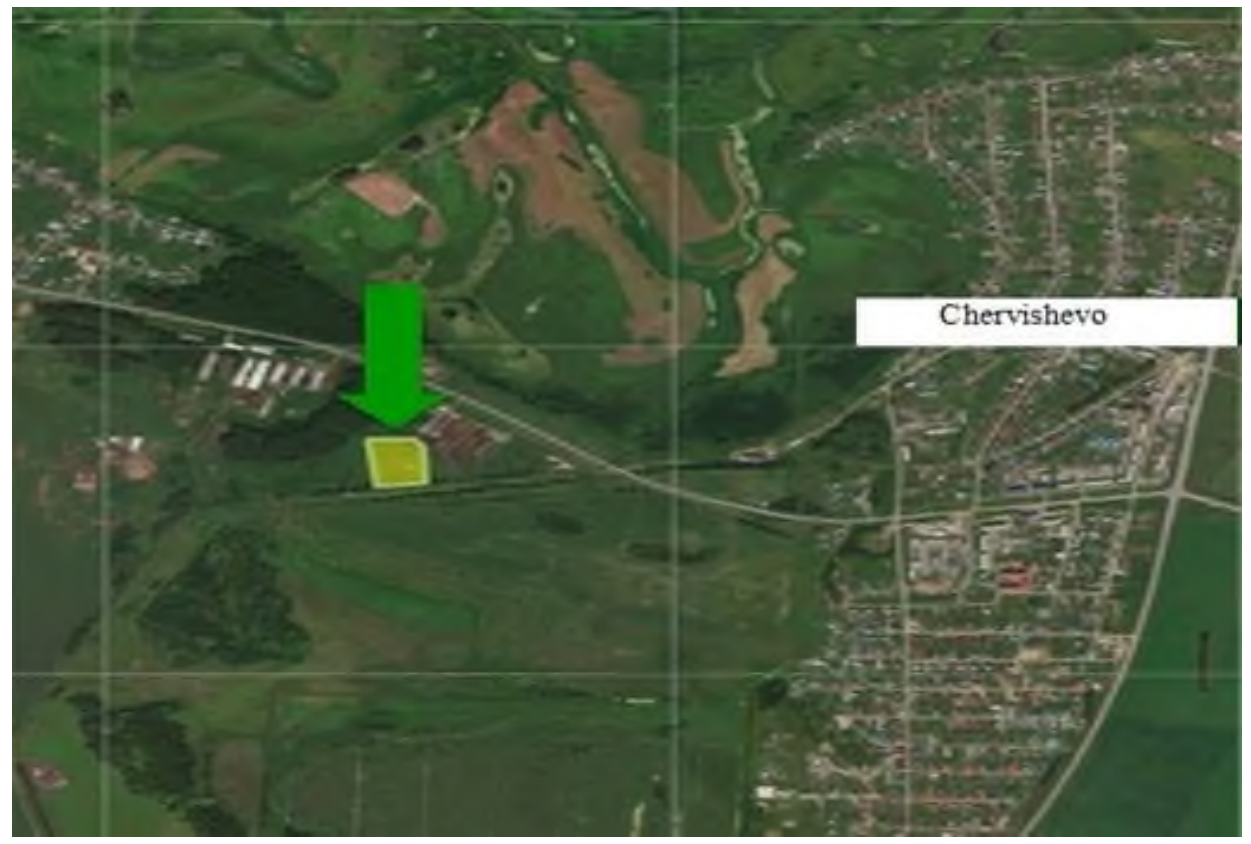

Fig. 3. Diagram of the location of investment site №2.

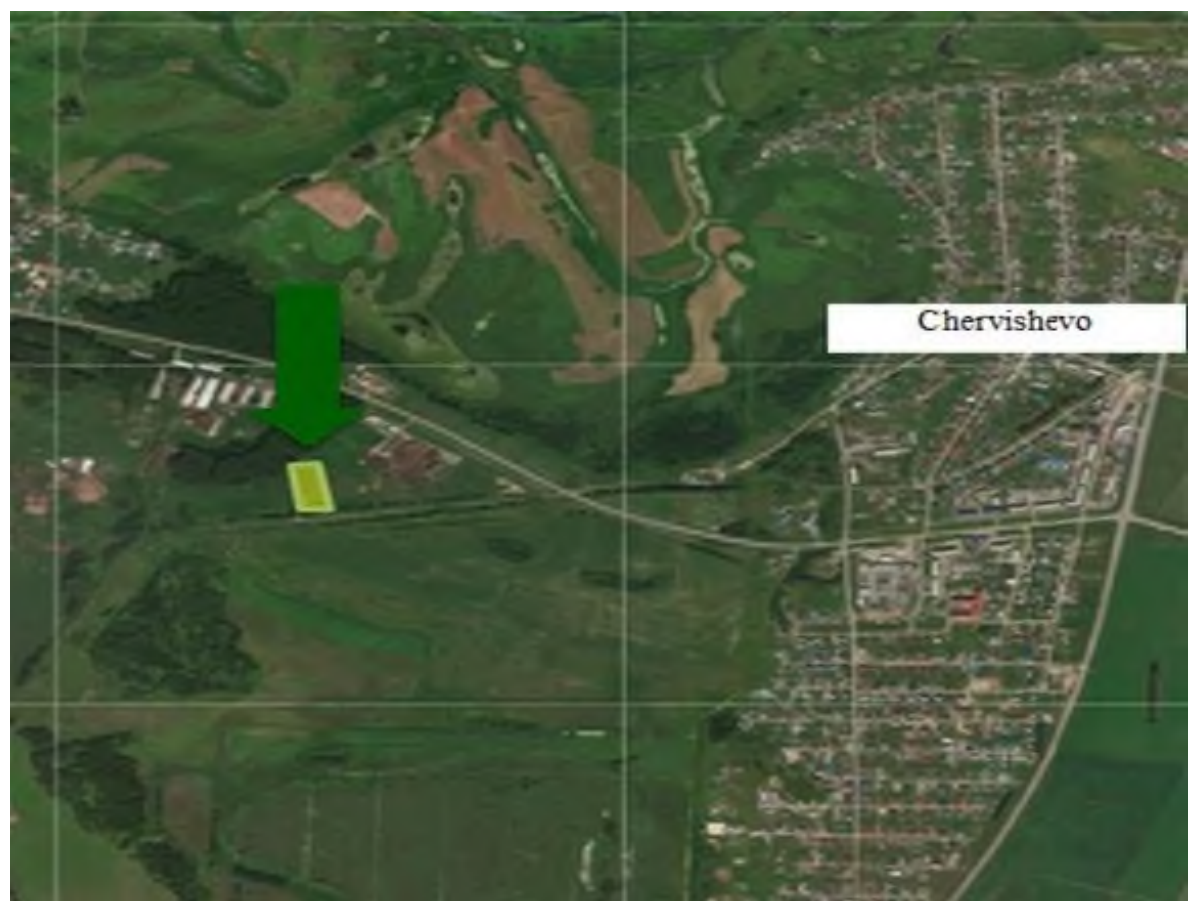

Fig. 4. Diagram of the location of investment site №3.

Table 1 shows the existing utilities located directly on the land plot or near the location. 
Table 1. Characteristics of existing engineering communications

\begin{tabular}{|c|c|c|c|c|c|}
\hline $\begin{array}{c}\text { Name of the land } \\
\text { plot }\end{array}$ & Size & $\begin{array}{l}\text { Access } \\
\text { roads }\end{array}$ & Electrosupply & $\begin{array}{c}\text { Gas } \\
\text { supply }\end{array}$ & $\begin{array}{l}\text { Water } \\
\text { supply }\end{array}$ \\
\hline $\begin{array}{c}\text { Investment } \\
\text { platform №1 } \\
\text { 72:17:2314003:643 }\end{array}$ & 2 hectares & $\begin{array}{l}\text { There } \\
\text { are }\end{array}$ & $\begin{array}{c}\text { Technological } \\
\text { connection to the } \\
\text { networks of JSC } \\
\text { Tyumenenergo is } \\
\text { possible from the } \\
\text { distribution } \\
\text { networks connected } \\
\text { to PS } 110 / 10 \\
\text { Chervishevo, by } \\
\text { building the } \\
\text { necessary electrical } \\
\text { network facilities }\end{array}$ & $\begin{array}{l}400 \\
\text { meters to } \\
\text { the } \\
\text { borders of } \\
\text { the land } \\
\text { plot }\end{array}$ & Absent \\
\hline $\begin{array}{c}\text { Investment } \\
\text { platform №2 } \\
\text { 72:17:2314003:646 }\end{array}$ & 2 hectares & $\begin{array}{l}\text { There } \\
\text { are }\end{array}$ & $\begin{array}{l}\text { Technological } \\
\text { connection to the } \\
\text { networks of JSC } \\
\text { Tyumenenergo is } \\
\text { possible from the } \\
\text { distribution } \\
\text { networks connected } \\
\text { to PS } 110 / 10 \\
\text { Chervishevo, by } \\
\text { building the } \\
\text { necessary electrical } \\
\text { network facilities }\end{array}$ & $\begin{array}{l}350 \\
\text { meters to } \\
\text { the } \\
\text { borders of } \\
\text { the land } \\
\text { plot }\end{array}$ & Absent \\
\hline $\begin{array}{c}\text { Investment } \\
\text { platform №3 } \\
\text { 72:17:2314003:894 }\end{array}$ & 1 hectares & $\begin{array}{l}\text { There } \\
\text { are }\end{array}$ & $\begin{array}{c}\text { Technological } \\
\text { connection to the } \\
\text { networks of JSC } \\
\text { Tyumenenergo is } \\
\text { possible from the } \\
\text { distribution } \\
\text { networks connected } \\
\text { to PS } 110 / 10 \\
\text { Chervishevo, by } \\
\text { building the } \\
\text { necessary electrical } \\
\text { network facilities }\end{array}$ & $\begin{array}{c}450 \\
\text { meters to } \\
\text { the } \\
\text { borders of } \\
\text { the land } \\
\text { plot }\end{array}$ & Absent \\
\hline
\end{tabular}

Let's look at the costs of engineering construction of investment sites, which are presented in the table 2 .

Table 2. The costs of engineering infrastructure of investment sites.

\begin{tabular}{|c|c|c|c|c|c|}
\hline $\begin{array}{c}\text { Name of the land } \\
\text { plot }\end{array}$ & $\begin{array}{c}\text { Builder } \\
\text { access } \\
\text { road, } \\
\text { thousand } \\
\text { rubles }\end{array}$ & $\begin{array}{c}\text { Electricity } \\
\text { supply, } \\
\text { thousand } \\
\text { rubles }\end{array}$ & $\begin{array}{c}\text { Approximate } \\
\text { annual rent } \\
\text { of the land } \\
\text { plot, } \\
\text { thousand } \\
\text { rubles }\end{array}$ & $\begin{array}{c}\text { Cost of } \\
\text { land } \\
\text { purchase, } \\
\text { thousand } \\
\text { rubles }\end{array}$ & $\begin{array}{c}\text { TOTAL, } \\
\text { thousands } \\
\text { rubles }\end{array}$ \\
\hline $\begin{array}{c}\text { Investment } \\
\text { platform №1 } \\
72: 17: 2314003: 643\end{array}$ & 624 & 920 & 293.8 & 2203.5 & 4041.3 \\
\hline $\begin{array}{c}\text { Investment } \\
\text { platform №2 } \\
72: 17: 2314003: 646\end{array}$ & 600 & 865 & 290.82 & 2181.15 & 3936.97 \\
\hline
\end{tabular}




\begin{tabular}{|c|c|c|c|c|c|}
\hline $\begin{array}{c}\text { Investment } \\
\text { platform №3 } \\
72: 17: 2314003: 894\end{array}$ & 612 & 980 & 162.4 & 1775.14 & 3529.54 \\
\hline
\end{tabular}

\section{Results}

Thus, investment site №3 has increased investment attractiveness. Comparative characteristics of investment sites were carried out to identify the most attractive land plot. In total, the most profitable and favorable from the point of view of the influence of factors is the investment site №3, since the main engineering communications are located either directly on the site or at a small distance, and its engineering arrangement will require the least expenses in the amount of 3,529.54 thousand rubles, which is certainly a positive point.

\section{Discussion}

Any locality (city, municipality) or separate building is built on a specific territory, site, characterized by certain conditions. Means of engineering training allow you to make the territory most suitable for the construction and operation of architectural structures and their complexes at the optimal cost of money.

A comprehensive analysis of the engineering arrangement of investment sites is carried out based on the following criteria:

- availability of available electricity capacity at the border of the investment site;

- cost of electricity supply to the investment site;

- availability of available gas capacity at the border of the investment zone

- cost of gas supply to the investment site;

- availability of available water capacity at the border of the investment site;

- cost of water supply to the investment site;

- distance from the Federal highway;

- availability of paved roads on the border of the investment site;

- the cost of bringing the road to the investment site;

- distance from the center;

- availability of sufficient space;

- availability and quality of labor resources;

- availability of places for training of labor resources;

- availability of urban planning documentation;

- type of permitted use of the land plot;

- availability (proximity) of social infrastructure facilities;

- the possibility of buying land by an investor in the property without building a production facility.

The current level of development of engineering technologies allows you to use various territories for construction. However, preference should be given to the most favorable areas for development, as well as living on them. Less convenient areas should be developed through engineering and technical measures related to changes in natural conditions, which complicates construction processes and causes significant material and monetary costs. 


\section{Conclusion}

1. Tyumen region has great potential and is a very attractive municipal area for both citizens and businesses. The district is located in close proximity to the center of strategic decision-making in the politics and economy of the entire region.

2. The investment attractiveness of land plots of the Tyumen municipal district is influenced by a set of factors (criteria) that determine the possibility of obtaining high incomes for the created objects and form a potential demand. These factors include the location and engineering arrangement of the territory.

3. Under the influence of investment attractiveness factors, similar land plots were formed on the territory of the Tyumen region, similar characteristics of which are the type of permit and the category of land.

4. After analyzing the engineering arrangement of investment sites, you can make a choice in favor of the most profitable investment site in terms of engineering communications. The most favorable site was site 3 , since the main engineering communications are located either directly on the site or at a small distance, and transport accessibility is also an attractive factor.

Thus, the conducted research will allow:

- attract the attention of external investors to the opportunities of the district and its investment attractiveness, which will help to increase the volume of investment in fixed assets,

- economic growth and social stability;

- carry out engineering development of the territory to the benefit of a potential investor;

- provide jobs for the local population.

\section{References}

1. A. Ermakova, T. Nurullina, Moscow economic magazine 10, 49 (2019)

2. A. Ermakova, Moscow economic magazine 2, 19 (2020)

3. A. Ermakova, Y. Zubareva, Strategic development of rural areas in the South of the Tyumen region (Tyumen industrial University, Tyumen, 2017)

4. A. Ermakova, Moscow Economic Journal 10, 50 (2019)

5. A. Kryakhtunov, O. Bogdanova, E. Chernykh, System for conservation of specially protected natural areas as sustainable urban development element. IOP Conference series: materials science and engineering (2017)

6. I. Kustysheva, IOP Conference Series: Materials Science and Engineering 262(1), 012166 (2017)

7. Y. Zubareva, I. Pivovarova, The national composition of the self-employed population of Siberia (according to the results of the census of 1897) 3, 129-134 (2019)

8. O Kirilova, O. Ustinova, Voprosy istorii 9, 34-44 (2019)

9. I. Pivovarova, Y. Putilina, Y. Zubareva, A. Mamadaliev, Russian Historical Journal 49(3), 1216-1223 (2018)

10. L. Oznobihina, Moscow Economic Journal 1, 7 (2020)

11. L. Oznobihina, S. Odintseva, Modern issues of land management, cadastre and land monitoring materials of the regional scientific and practical conference, 125-130 (2016)

12. L. Oznobihina, Moscow Economic Journal 2, 20 (2020)

13. A. Oznobihina, L. Oznobikhina, Moscow Economic Journal 1, 8 (2019) 